\title{
Physical habitat simulation for small-sized characid fish species from tropical rivers in Brazil
}

\author{
Hersília de Andrade e Santos ${ }^{1}$, Cecília Gontijo Leal ${ }^{2}$, Paulo Santos Pompeu ${ }^{3}$, \\ Ceceo Chaves ${ }^{3}$ and Stephanie Fernandes Cunha ${ }^{1}$
}

Physical habitat simulation (PHABSIM) is an important step of the instream flow incremental methodology (IFIM), which is applied to establish environmental flow regimes. This study applied the PHABSIM in two reaches of the Velhas river basin, whose long-term discharges are similar but are under different degrees of impact. Suitability curves were obtained for fish species using traditional methods (Astyanax sp., Piabarchus stramineus, Piabina argentea and Serrapinnus heterodon) and generalized additive models for fish density (Astyanax sp., P. argentea and S. heterodon). The results of habitat use depended on the method for curves generation. Applying the suitability curves by traditional methods, different discharge scenarios were simulated. The flow increasing from a dry scenario to a discharge of 1 year of return promotes a possible habitat increase for all species. However, the same hydrological flow percentiles produce different habitat proportions in different rivers. This work demonstrates that regardless of how suitability curves for the Neotropical species are generated, caution should be taken when applying them. However, the PHABSIM method allows more complex analyses than the traditional approaches based on minimal flow estimations, which is usually applied in South America.

Keywords: Environmental flow, GAM models, Habitat suitability curves, Hydrological scenarios, Velhas River.

A simulação de habitat para espécies de peixes (PHABSIM) é uma etapa importante do método Instream Flow Incremental Methodology (IFIM), cuja aplicação está relacionada a determinação da vazão ecológica. O presente estudo aplicou PHABSIM em dois trechos da bacia do rio das Velhas, cujas vazões de médio prazo são semelhantes, mas sob condições de conservação ambiental diferente. Curvas de aptidão foram obtidas para Astyanax sp., Piabarchus stramineus, Piabina argentea e Serrapinnus heterodon através do método tradicional e ajustando modelo aditivos generalizados (Astyanax sp., P. argentea e $S$. heterodon). Os resultados sugerem uso de habitats diferentes dependendo do modelo utilizado para gerar as curvas. Aplicando as curvas obtidas pelo método tradicional no PHABSIM, diferentes cenários de vazão foram simulados. O aumento da vazão para cheia de um ano de retorno aumenta o habitat provável para todas as espécies. Entretanto, mesmo cenário de vazão, fornecido por análise de hidrológica de percentis de ocorrência, fornece diferente proporção de habitat em diferentes rios. O trabalho demonstra que curvas de aptidão para espécies neotropicais, independentemente da forma de geração, devem ser usadas com cautela. Entretanto, o método PHABSIM permite análises mais elaboradas do que as tradicionais estimativas de vazão mínima empregadas na América do Sul.

Palavras-chave: Cenários hidrológicos, Curvas de aptidão, Modelos GAM, Rio das Velhas, Vazão ecológica.

\section{Introduction}

An increase in water demand results in several conflicts between the development of freshwater resources (as water and energy sources) and the conservation of biologically diverse/integrated ecosystems (World Commission on Dams, 2000). Therefore, the evaluation of how the flow regime of a river can be altered for the purposes of water resource development and management, while maintaining accepted levels of degradation, is known as the science of environmental flow assessment (Tharme, 2003).

Several methods have been proposed to estimate environmental flows (O'Keeffe et al., 2002) to maintain minimal levels of habitat heterogeneity for aquatic organisms. Some

${ }^{1}$ Departamento de Engenharia Civil, Centro Federal de Educação Tecnológica de Minas Gerais, Av. Amazonas 7675, 30510000 Belo Horizonte, MG, Brazil. (HAS) hsantos@cefetmg.br, Ohttps://orcid.org/0000-0002-1268-2753 (corresponding author), (SFC) stephaniefernandesc@hotmail.com

${ }^{2}$ Programa de Capacitação Institucional, Museu Paraense Emílio Goeldi, Av. Perimetral, 1901, Terra Firme 66077-830 Belém, PA, Brazil (CGL) c.gontijoleal@gmail.com

${ }^{3}$ Departamento de Biologia, Universidade Federal de Lavras, Campus Universitário, Caixa Postal 3037, 37200-000 Lavras, MG, Brazil. (PSP) pompeups@gmail.com, (CC) ceceochaves@yahoo.com.br 
of these methodologies include only hydrological simulation, while others consider also the effects of hydrology based on habitat availability indicators (Bowen et al., 2003; Barquín, Martínez-Capel, 2011).

The instream flow incremental methodology (IFIM) is the most applied habitat simulation method in North America (Reiser et al., 1989) and has been useful for assessing the effects of altered stream flow regimes, for evaluating habitat improvement projects and for assisting in regulating releases from water storage projects (Katopodis, 2003). The IFIM has a component known as the physical habitat simulation system, PHABSIM (Bovee et al., 1998), which consists of combining the results of hydraulic models with the results of a biological model of habitat selection. For that, it is necessary to obtain habitat suitability curves and the weighted usable area (WUA) for a focal species (Bovee et al., 1998).

Despite the wide range of applications for PHABSIM, there are some concerns that it does not consider water quality, sediment transport and other constraints on habitat suitability and population abundances (Spence, Hickley, 2000) and that there are statistical uncertainties in the PHABSIM output (Ayllón et al., 2012). Furthermore, also criticized is the assumption that constant suitability, i.e., the target species and life-stage preference for habitat variables, does not change spatially or temporally (Gore, Nestler, 1988).

In Brazil, as in Central and South America, environmental agencies adopt hydrological methodologies for establishing acceptable environmental flows (Tharme, 2003). These methods rely primarily on the use of hydrological data, usually in the form of naturalized, historical monthly or daily flow records, for making environmental flow recommendations (Milhous et al., 1990). However, the hydrological methods provide flow percentiles, such as $\mathrm{Q}_{95}$, defined as the flow that equals or exceeds $95 \%$ of the flow record. This and other percentiles are considered inappropriate for flow management because there are large site variations that lead to poor relationships between these percentiles and the amount of suitable habitat for target aquatic species (Armstrong, Nislow, 2012). Additional deficiencies of the method are created with the existence of state laws in Brazil, which use a different percentile $\left(\mathrm{Q}_{7,10}\right.$ or $\left.\mathrm{Q}_{90}\right)$ for minimum flows, leading to different guidelines for nationwide rivers.

To advance in the hydrological methods of flow assessment, it is necessary to evaluate other approaches that consider the effects of flow modification on the amount of habitat availability for focal species. This consideration would help to improve the establishment of new thresholds in Brazilian watersheds for the protection of the entire river community. This paper aimed at i) analyzing the applicability of the PHABSIM for Neotropical fishes, ii) comparing suitability curves to a regression model for fish density, and iii) evaluating the relation between flow discharge and changes on habitat availability in rivers with different levels of preservation.

\section{Material and methods}

Study area. The Velhas River is one of the main tributaries of the São Francisco River (Fig. 1). The Velhas River drainage area is entirely located in Minas Gerais State and is $29.173 \mathrm{~km}^{2}$. This river extends $761 \mathrm{~km}$ and is impacted by mining, agriculture and urban activities. In the first $100 \mathrm{~km}$ from its source, domestic and industrial wastes are dumped into the river from the Metropolitan Region of Belo Horizonte, which over the years has contributed to the pollution and siltation of the river. The several cities that occur along the Velhas River contribute to its degradation; however, the condition of the upper Velhas River has changed due to a recent installation of several sewage treatment stations (Alves, Pompeu, 2005).

Two reaches were chosen for analyses based on their similar sizes and discharge rates. Median long-term discharge was used to select the reaches. The first reach is located in the main channel of the Velhas River, upstream of the metropolitan region of Belo Horizonte $\left(20^{\circ} 06^{\prime} 01.44^{\prime \prime} \mathrm{S}\right.$, $\left.43^{\circ} 47^{\prime} 35.85^{\prime \prime} \mathrm{W}\right)$. The reach receives domestic sewage from the Itabirito municipality and mining waste from the upstream region. The site is heavily silted, and the riparian vegetation is sparse or absent. The second reach is located in the Curimataí River $\left(17^{\circ} 59^{\prime} 33.3^{\prime \prime} \mathrm{S}, 44^{\circ} 10^{\prime} 48.2^{\prime \prime} \mathrm{W}\right)$, a tributary of the Velhas River. Although many small cities are located nearby, the Curimataí River is less disturbed and can be considered a reference river within the basin (Alves, Pompeu, 2005).

Fish and habitat sampling. Fish sampling occurred during the dry season of September 2007 and followed Leal et al. (2011). Each reach was sampled in 2 days along $500 \mathrm{~m}$ (straight main channel) during daylight hours using seines (6 $\mathrm{m}$ long, $5 \mathrm{~mm}$ mesh) and kick nets $(80 \mathrm{~cm}$ in diameter, $1 \mathrm{~mm}$ mesh). The use of different equipment was applied to encompass all kinds of habitats, which were defined as homogeneous areas considering substrate, water velocity and depth (e.g., shallow gravel bed riffle, mid-depth sandy shore, deep pool). Each habitat was considered a sampling site, thus totaling 20 samples in each river. Within and between the rivers, each type of habitat was replicated. The individuals collected were fixed in $10 \%$ formalin, and in the laboratory, they were identified to the species level and preserved in $70 \%$ ethanol. Voucher specimens of each species were deposited in the fish collection of the Coleção Ictiológica do Nupelia (NUP 7265, 7269, 7270, 7271), Maringá City, Paraná State, Brazil.

Due to limitations of the sampling methods for deep waters, the samples were taken in wadable areas. After each seine or kick net pass, the area $\left(\mathrm{m}^{2}\right)$ and depth were obtained, and the average velocity was measured using a propeller flowmeter at $60 \%$ of the total depth. The depth was measured by the handle of the propeller flowmeter, which has a scale meter on it, and $60 \%$ of the total depth was calculated to locate the propeller for the velocity mea- 


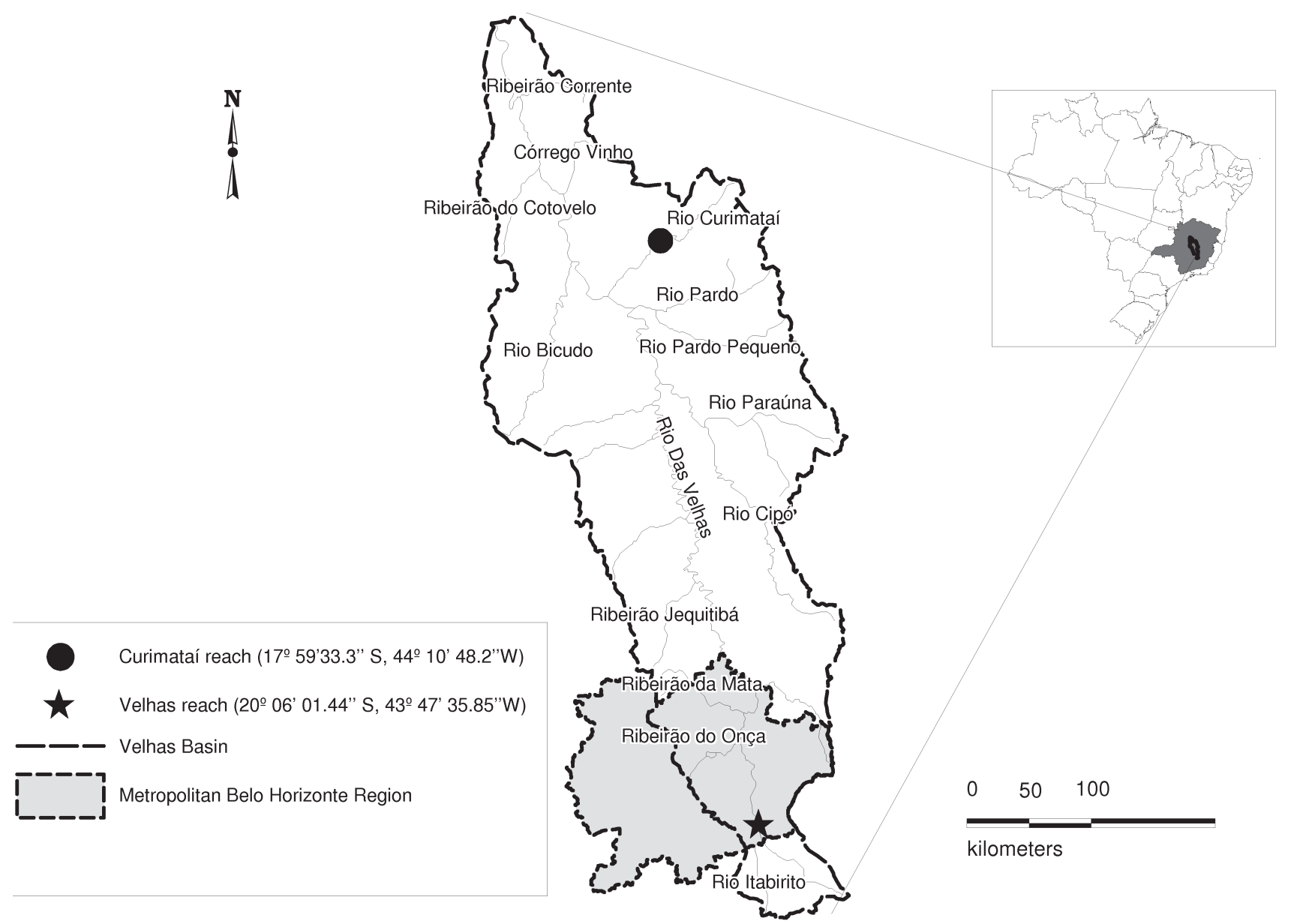

Fig. 1. The Velhas river basin in the Brazilian territory, whose drainage area is $29.173 \mathrm{~km}^{2}$.

surement. The dominant substrate was determined visually by granulometric analysis, which is defined as the median of the proportion of each category ordered in a size gradient. The classes were divided according to Bovee (1986), and each substrate category was related to one number of the channel index (CI) according to the manual of River 2D (Steffler, Blackburn, 2002): silt (diameter smaller than 0.3 $\mathrm{mm}, \mathrm{CI}=3$ ) sand (diameter $0.3 \mathrm{~mm}$ to $2 \mathrm{~mm}, \mathrm{CI}=4$ ), small gravel (diameter $2 \mathrm{~mm}$ to $50 \mathrm{~mm}, \mathrm{CI}=5$ ), cobble (diameter $50 \mathrm{~mm}$ to $200 \mathrm{~mm}, \mathrm{CI}=6$ ), boulder (diameter $200 \mathrm{~mm}$ to $400 \mathrm{~mm}, \mathrm{CI}=7$ ), bedrock (diameter bigger than $400 \mathrm{~mm}, \mathrm{CI}$ $=8)$, and roots and leaves $(\mathrm{CI}=9)$.

Suitability curves and regression models for fish density. Water velocity, depth and substrate were used to create suitability curves. Adults and sub-adults of four small-sized ( $<$ $10 \mathrm{~cm}$ in standard length) species, Astyanax sp., Piabarchus stramineus (Eigenmann, 1908), Piabina argentea Reinhardt, 1867 and Serrapinnus heterodon (Eigenmann, 1915), were considered for habitat use analyses based on the length at first maturity (L50). These species are widespread in the Velhas River basin (Alves, Pompeu, 2001). These species were selected because they were the most abundant in the studied reaches (Leal et al., 2014) and were thus considered good models to test the applicability of the PHABSIM in the basin.

Based on the L50, the total length ranged from $2.05 \mathrm{~cm}$ to $4.2 \mathrm{~cm}$ for individuals of Astyanax sp. congeneric species, from $4.1 \mathrm{~cm}$ to $4.5 \mathrm{~cm}$ for $P$. stramineus, from $2.79 \mathrm{~cm}$ to $3.75 \mathrm{~cm}$ to $P$. argentea and higher than $3.2 \mathrm{~cm}$ for $S$. heterodon (Gomiero et al., 2007; Castro et al., 2010; Gonçalves et al., 2011; Lourenço et al., 2015).

The habitat use for each species in both reaches was compared with the habitat availability in all reaches, as in Freeman et al. (1997). The suitability curves were obtained by dividing the proportional abundance of species in each class by the proportional number of available sites (Bovee, 1986). The curves were standardized by the maximum obtained value of the obtained suitability. All suitability curves were processed using the HabSel software (Jowett, 2011), which produces histograms that are smoothed by the kernel and standardize the curves. The sampled habitat use included 31 points for Astyanax sp., 9 points for $P$. stramineus, 33 for P. argentea and 30 for $S$. heterodon.

As suitability curves do not provide levels of uncertainties associated with the fitted values, regression models were used to fit the fish density to habitat structure. General additive models (GAMs) were applied for Astyanax sp., P. argen- 
tea and $S$. heterodon, which have a polynomial form based on a Poisson distribution with a $\log$ link function. Models were processed using the HabSel software (Jowett, 2011), in which the fish density (abundance divided by sampled area) was the dependent variable; velocity, depth and channel index were the independent variables. The coefficient of determination $\left(\mathrm{R}^{2}\right)$ and $\mathrm{p}$-values were determined for the GAM.

PHABSIM. Hydrodynamic Model. For each river (the Curimataí and the Velhas), the bed river geometry was obtained for a one $\mathrm{km}$-long reach using a total station during a two-month field trip (in July/August 2007 for Velhas and July/August 2008 for Curimataí). The grids have approximately 2297 points at the Velhas reach and 1900 points at the Curimataí (the space between the points was, on average, $3 \mathrm{~m}$ ), encompassing the river channel and in the banks.

The substrate of the riverbed was sampled to provide information for model roughness and for the last step of PHABSIM, which is the analysis of habitat availability for the chosen species. The substrate was classified according Bovee (1986) during the fish habitat sampling. The low water turbidity enabled the visual analyses of the substrate in the wadable regions, while in the deepest areas, the substrate was sampled using a dredge.

The PHABSIM was processed using the free software River 2D (University of Alberta, 2002), which is a twodimensional depth averaged finite-element hydrodynamic model that has been customized for fish habitat evaluation studies. The River2D model suite consists of four programs: R2D_Bed, which creates the river topography from the points collected with total station; R2D_Mesh, which creates a domain with the boundary conditions of the chosen scenario of discharge; R2D_Ice, which creates the freezing condition for the studied reach; and River2D, which solves the numerical model. This study applied the programs R2D Bed, R2D_Mesh and River2D.

Four scenarios were studied by simulating rainy or dry seasons for Curimataí and Velhas Rivers. All the boundaries conditions (Tab. 2) were obtained by hydrologic analyses of the historical data series of both sites. The discharge in the rainy scenario was related to recurrence of a one-year flood. The mesh quality was evaluated by the mesh quality index (QI). QI values between 0.15 and 0.5 indicate good conditions (Tab. 1), which means that the reach domain was well discretized (the major parts of reach are represented by the built mesh). At the Velhas reach, two islands were defined as intern boundaries.
Steady flow regime was simulated for each discharge scenario using RIVER 2D (Steffler, Blackburn, 2002), and the results were calibrated by measurements of velocities and discharge completed in the field.

Hydrodynamic model compared with field measurements. The field measurements of water velocity allowed for validating the numerical model results for dry scenarios. A propeller flowmeter collected the velocity in 30 different cross-sections along each studied reach. In each cross section, the flowmeter was positioned at 20\%, 50\% and $80 \%$ of the cross-section width. A sounder measured depth in a range of $0.6 \mathrm{~m}$ to $79 \mathrm{~m}$. If the depth was less than $1.2 \mathrm{~m}$, the $60 \%$ depth velocity was sampled by the propeller flowmeter. If the depth was greater than $1.2 \mathrm{~m}$, the velocities at $20 \%$ depth and $80 \%$ depth were measured. This procedure was performed to obtain the mean velocity for the column of the cross section.

The producer accuracy for flowmeter is $\pm 0.03 \mathrm{~m} / \mathrm{s}$ and for the depth sounder $\pm 1 \%$. A differential GPS collected the UTM coordinates of each measurement grid point in each reach, and the estimated position accuracy was $10 \mathrm{~mm}$ for latitude and longitude and $30 \mathrm{~mm}$ for elevation.

WUA Method. The weighted usable area (WUA) was obtained by the habitat model of River 2D software. The WUA is calculated as the product of a composite suitability index (CSI), which was evaluated at every node in the domain and the area associated with that node (Steffler, Blackburn, 2002). It is necessary to calculate the following: habitat suitability of use index (SI) curves for each fish species and life stage of interest (for depth, velocity, and channel index); the channel index for the entire computational mesh, which is a descriptive code for substrate or cover (hiding places); and depth and velocity over the entire computational mesh, which is provided by the hydrodynamic model. In this study, the channel index for the entire reach was obtained by substrate characterization in the field.

\section{Results}

Fish samples. A total of 284 individuals of the studied species were captured in the Curimataí reach and 511 were sampled in the Velhas reach (Tab. 2). Astyanax sp. and Piabina argentea were the most abundant species in Velhas, and $A s$ tyanax sp. and Serrapinnus heterodon were the most abundant in Curimataí reach.

Tab 1. Simulated scenarios (discharge and elevation) and mesh details (space and quality index-QI) for the two evaluated sites in the dry and rainy seasons

\begin{tabular}{lccccc}
\hline Reach & Correspondent season & Inlet discharge $\left(\mathrm{m}^{3} / \mathrm{s}\right)$ & Outlet water surface elevation $(\mathrm{m})$ & Mesh space & QI value \\
\hline \multirow{2}{*}{ Velhas } & Dry & 11.3 & 741.61 & 9 & 0.23 \\
& Rainy & 79.5 & 742.27 & 9 & 0.22 \\
\multirow{3}{*}{ Curimataí } & Dry & 1.86 & 539.88 & 5 & 0.35 \\
& Rainy & 104 & 542.30 & 5 & 0.42 \\
\hline
\end{tabular}


Suitability curves and regression model for fish density. Astyanax sp. and Piabarchus stramineus used areas with comparatively higher velocity (over $1.5 \mathrm{~m} / \mathrm{s}$ ), while Piabina argentea and Serrapinnus heterodon were found in areas with a lower current (0.5 and $1 \mathrm{~m} / \mathrm{s}$, respectively) (Fig. 2a). The depth use was different for $P$. stramineus, which was found in deeper areas (up to $140 \mathrm{~cm}$ ). The other species used areas between 80 and $100 \mathrm{~cm}$ depth (Fig. 2b). The analyses of substrate use indicated that all species were found in higher abundance in cobble, although there was some use of silt and sand areas for $S$. heterodon and boulder, bedrocks and roots/leaves for Astyanax sp. (Fig. 2c).

The p-value of GAM models was statistically significant just for $P$. argentea, but different single variables were related to the species density (Tab. 2). GAM models predicted high densities of $S$. heterodon at lower velocities (Fig. 3a) and at $80 \mathrm{~cm}$ depth (Fig. 3b). A similar depth profile was predicted for $P$. argentea (Fig. 3b) which presented higher densities in cobble substrate areas (Channel index $=6$; Fig. $3 \mathrm{c}$ ).

PHABSIM. Hydrodynamic model compared with field measurements. The maximum values of velocities produced by the hydrodynamic model $(1.71 \mathrm{~m} / \mathrm{s}$ at Velhas and $1.37 \mathrm{~m} / \mathrm{s}$ at Curimataí) were higher than those of the field measurements $(1.54 \mathrm{~m} / \mathrm{s}$ at Velhas and $1.19 \mathrm{~m} / \mathrm{s}$ at Curimataí) for both reaches (10\% at Velhas and $13 \%$ at Curimataí). Velocity changes along the reaches followed the same pattern of variation (Figs. 4a, c), although in section 15 of the Velhas reach, the high velocity registered by the flowmeter was not represented by the model (Fig. 4a).

For the Velhas reach, the depth of hydrodynamic model $(4.39 \mathrm{~m})$ was lower $(13 \%)$ in the maximum value than that in the field measurements $(5 \mathrm{~m})$, although the tendencies along the stretch were similar (Fig. 4b). The maximum depth (2.24 $\mathrm{m})$ was very similar $(6.25 \%)$ in the Curimataí measurements and in the hydrodynamic scenario $(2.1 \mathrm{~m})$, although the model has diminished variation compared to that observed in the field (Fig. 4d).

Hydrodynamic. In the dry season scenario, the hydrodynamic model of the Velhas reach provided depths from 0 to $4.39 \mathrm{~m}$ and velocities from 0 to $1.71 \mathrm{~m} / \mathrm{s}$ (Fig. 5a). For the rainy scenario (Fig. 5b), the river became deeper (depth ranged from 0 to $5.39 \mathrm{~m}$ ) and faster (velocity ranged from 0 to $3.77 \mathrm{~m} / \mathrm{s}$ ). An island was observed in the dry scenario in the Velhas reach, which disappeared completely during the rainy scenario.

The hydrodynamic results for the Curimataí reach varied from 0 to $2.29 \mathrm{~m}$ in depth and from 0 and to $1.37 \mathrm{~m} / \mathrm{s}$ in velocity (Fig. 5c) in the dry scenario. Under these conditions, one island formed in the upper side of the reach. During the rainy events, the maximum depth was 4.44 and the highest velocity achieved $3.08 \mathrm{~m} / \mathrm{s}$ (Fig. $5 \mathrm{~d}$ ).

WUA. Considering all reaches and scenarios evaluated, Serrapinnus heterodon presented the highest percentage of

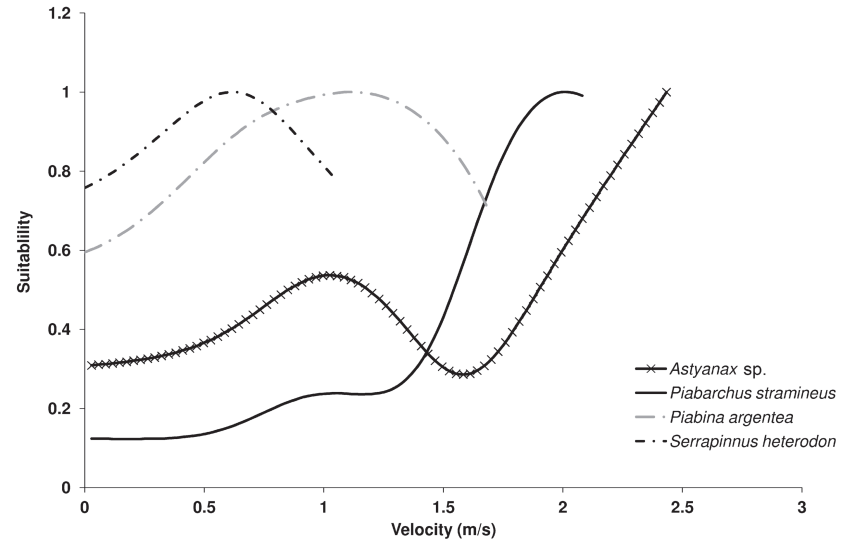

(a)

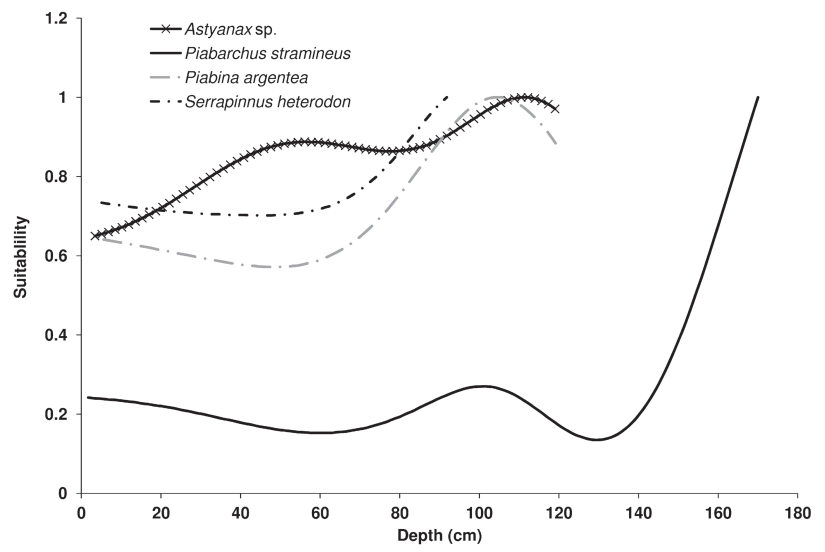

(b)

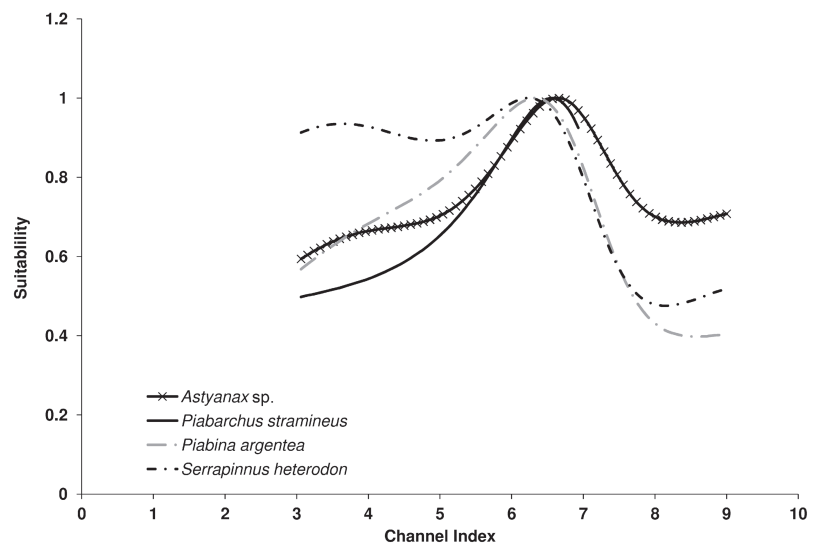

(c)

Fig. 2. Suitability curves for velocity $(\mathrm{m} / \mathrm{s})$ (a), depth (b) and channel index (c) for the four studied species at the Velhas river basin.

available habitat (WUA), followed by Piabina argentea, Astyanax sp. and Piabarchus stramineus (Figs. 6-7). There were no major differences in habitat availability for these species between the two reaches. However, for all of the species, there was an important reduction in the availability of habitat when lower flows (dry season) were simulated. This reduction was particularly pronounced for P. stramineus (Fig. 8). 
PHABSIM for fish species from tropical rivers

Tab 2. Fish species abundance in both reaches, coefficients and p-value for GAM models

\begin{tabular}{|c|c|c|c|c|c|c|c|}
\hline & P. stramineus & \multicolumn{2}{|c|}{ Astyanax sp. } & \multicolumn{2}{|c|}{ P. argentea } & \multicolumn{2}{|c|}{ S. heterodon } \\
\hline N Velhas River & 0 & \multicolumn{2}{|c|}{10} & \multicolumn{2}{|c|}{273} & \multicolumn{2}{|c|}{1} \\
\hline N Curimataí River & 9 & \multicolumn{2}{|c|}{224} & \multicolumn{2}{|c|}{100} & \multicolumn{2}{|c|}{178} \\
\hline P-value & - & \multicolumn{2}{|c|}{0.082} & \multicolumn{2}{|c|}{0.000} & \multicolumn{2}{|c|}{0.093} \\
\hline $\mathrm{R}^{2}$ & - & \multicolumn{2}{|c|}{0.485} & \multicolumn{2}{|c|}{0.715} & \multicolumn{2}{|c|}{0.476} \\
\hline Parameter & - & Coefficient & $P$ & Coefficient & $P$ & Coefficient & $P$ \\
\hline Constant & - & 0.3 & 0.696 & 5.279 & 0 & -1.128 & 0.141 \\
\hline Channel Index & - & -0.009 & 0.919 & -0.672 & 0.004 & 0.028 & 0.784 \\
\hline Depth (m) & - & 0.01 & 0.376 & -0.027 & 0.025 & 0.018 & 0.035 \\
\hline Velocity (m/s) & - & -0.223 & 0.489 & -0.308 & 0.729 & 1.621 & 0.007 \\
\hline
\end{tabular}
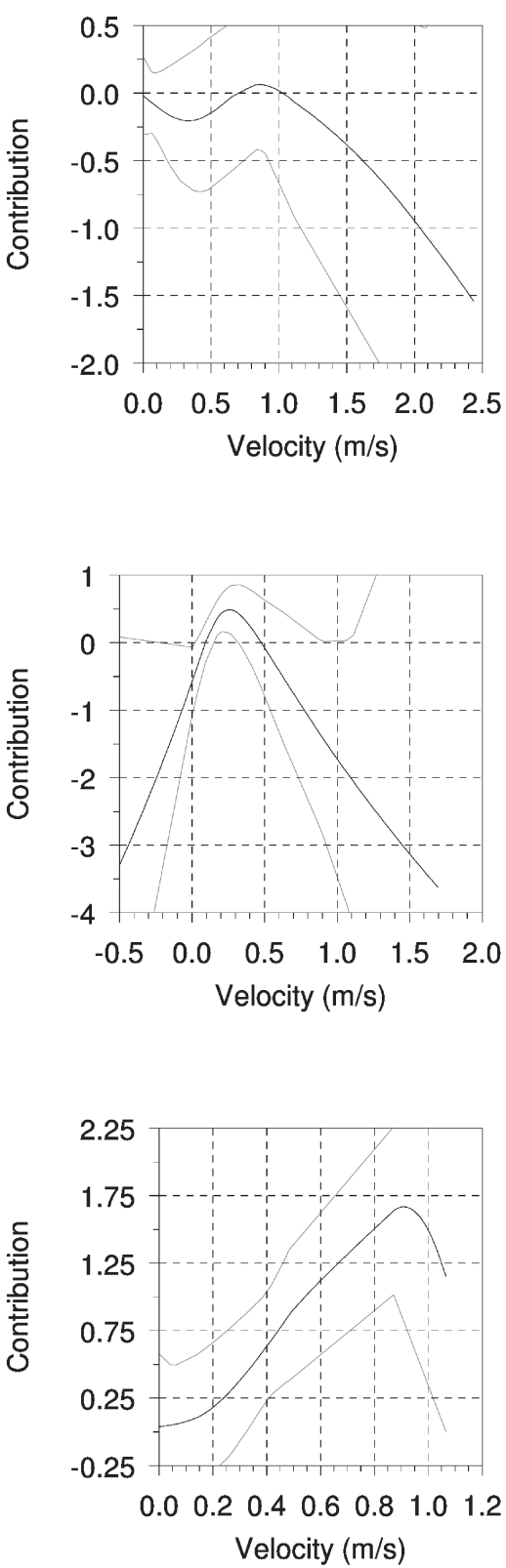

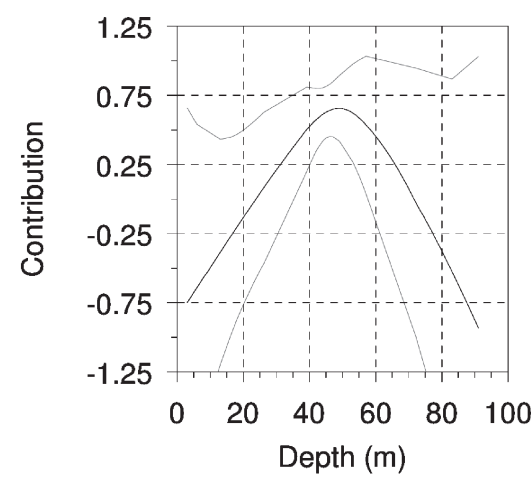

(a)

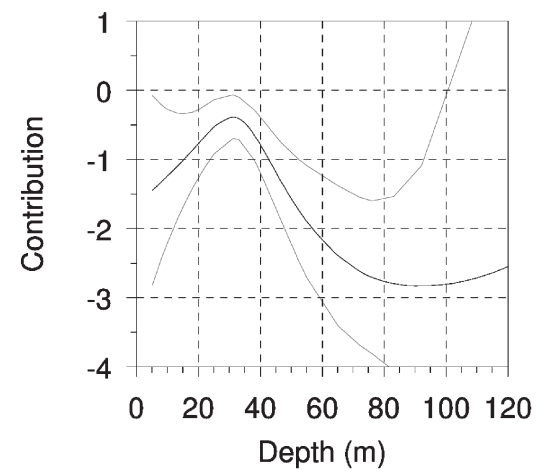

(b)

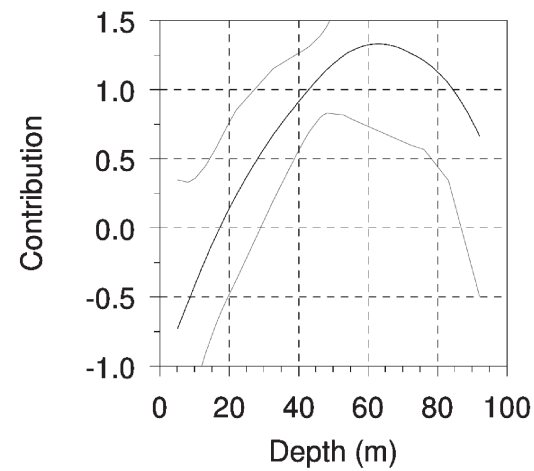

(c)
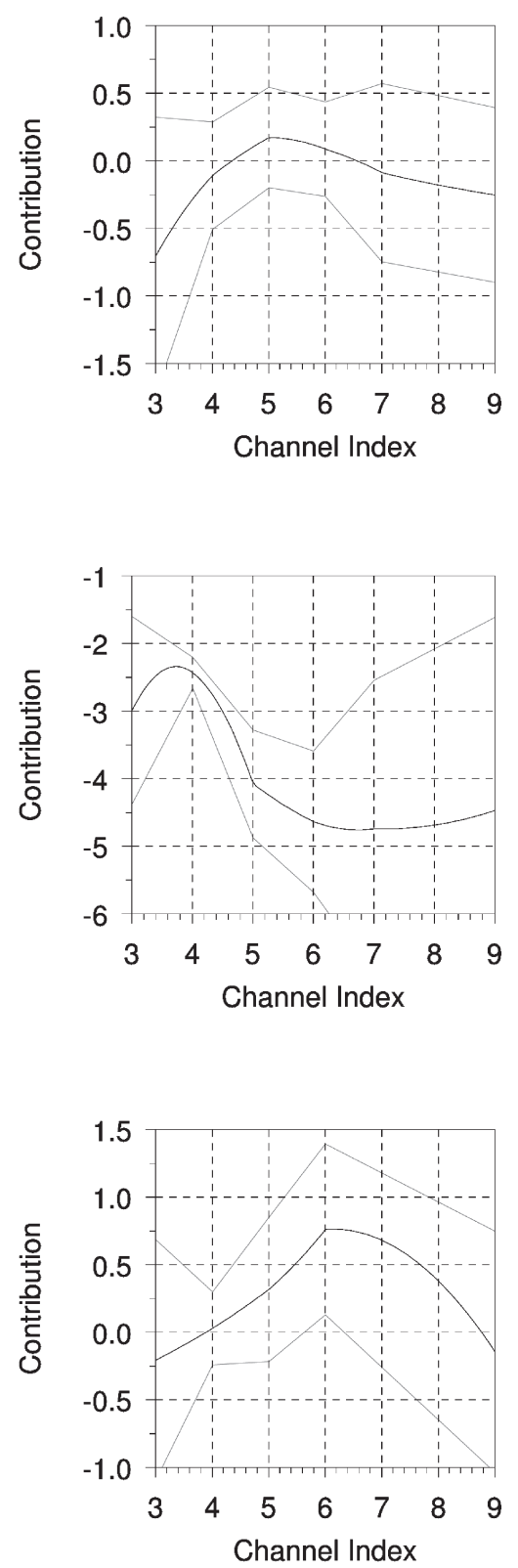

Fig. 3. Generalized additive model (GAM) for Astyanax sp. (a), Piabina argentea (b) and Serrapinnus heterodon (c). The GAM curves show the natural $\log$ contribution of each habitat function $(\mathrm{v}=$ velocity, $\mathrm{d}=$ depth and $\mathrm{CI}=$ channel index) to the model $\ln ($ standardized density $)=$ constant $+v+d+C$. Light gray lines around the GAM curves indicate $95 \%$ confidence intervals. 


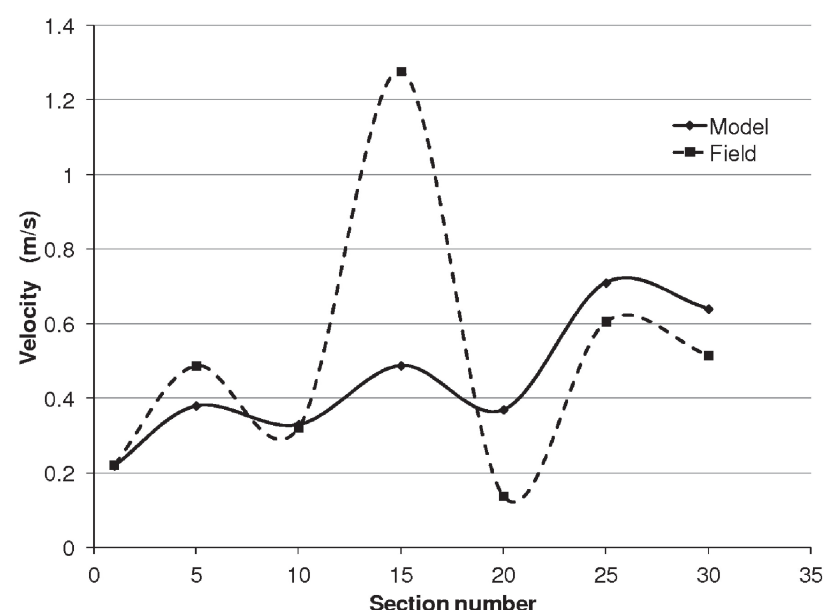

(a)

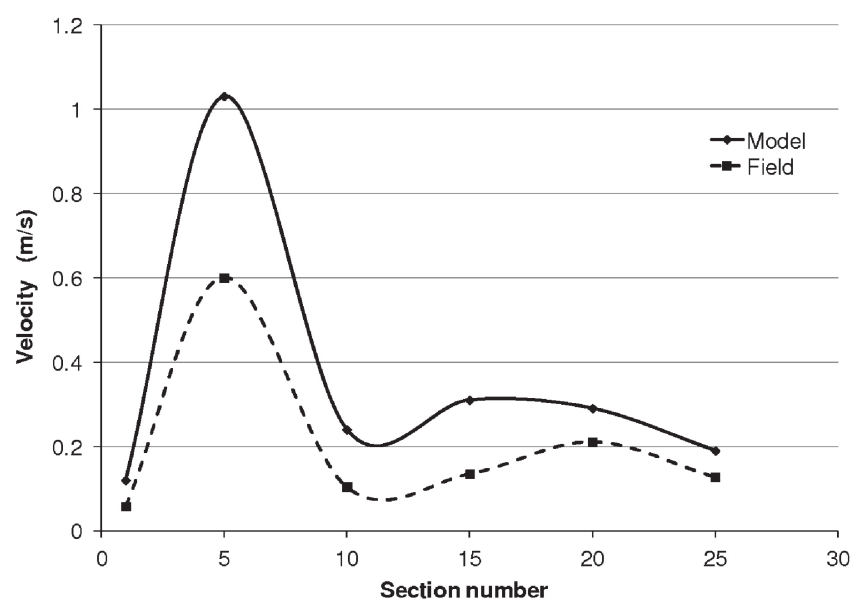

(c)

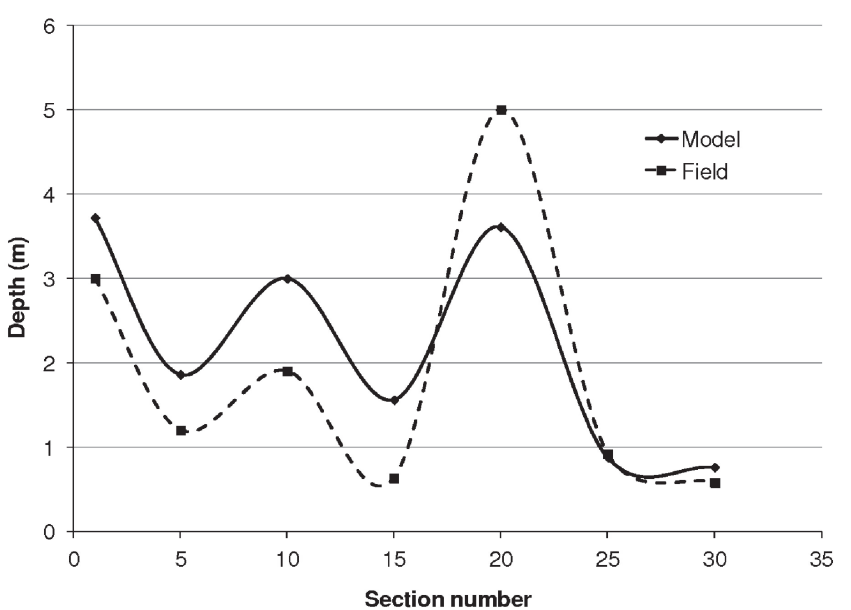

(b)

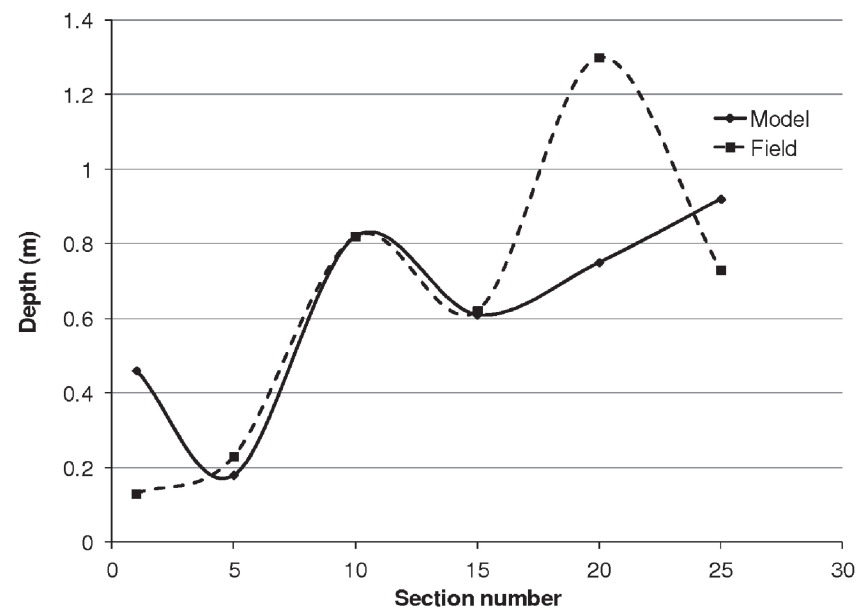

(d)

Fig. 4. The velocities and depth comparison between the field measurement and the numerical model for points in $50 \%$ cross-section width of the Velhas reach (a-b) and in 50\% width of the Curimataí reach (c-d).

In both reaches, the greater WUA areas (red region) were found in the main flow even for the rainy scenario (Figs. 6-7). Serrapinnus heterodon presented higher WUA areas in all scenarios for both reaches. Its medium weighted use area (green region) ranged from 14\% (at Curimataí reach in rainy scenario) to $60 \%$ (at Velhas reach in dry scenario). Piabina stramineus presented lower WUA areas in all scenarios for both reaches. Its medium weighted use area (green region) ranged from $1 \%$ (at Curimataí reach in rainy scenario) to $50 \%$ (at Curimataí reach in dry scenario). The flow change created more WUA differences at the Curimataí reach than those at the Velhas reach.

\section{Discussion}

The flow regime plays an important role in the biophysical structure and functioning of river and floodplain ecosystems, regulating the physical nature of river channels relating to sediment deposition and water quality. It is thus central to regulate the aquatic biodiversity and key ecological processes (Naiman et al., 2002). As an attempt to relate fish demands to the flow/habitat regime in a tropical river basin, the habitat use of four Neotropical species was used to investigate flow influences in habitat quantity.

The preference (Costa et al., 2013; Teresa, Casatti, 2013) and habitat use (Mazzoni et al., 2011) of Neotropical fish was obtained by several studies that can provide important information for management tools such as PHABSIM. However, none of these studies evaluated how the amount of the available habitat would vary due to flow variations.

In this study, Piabarchus stramineus used fast $(>1.5 \mathrm{~m} / \mathrm{s})$ and deep areas of the river $(>140 \mathrm{~cm})$, while the other three species occupied shallower and slower habitats. The WUA analyses indicated that the habitat availability for $P$. stramineus is more sensitive to flow alteration. Caution should be applied when interpreting these standards of $P$. stramineus due to the small number of sampled individuals. However, rare information in the literature about habitat use of this species reinforces the relevance of these results and would be complemented by further studies.

Overall, increases in flow led to increases in the WUA for all studied species in both rivers. However, in the rainy scenario, the simulation quantified larger habitat (WUA) at the Curimataí reach than that at the Velhas. On the other 


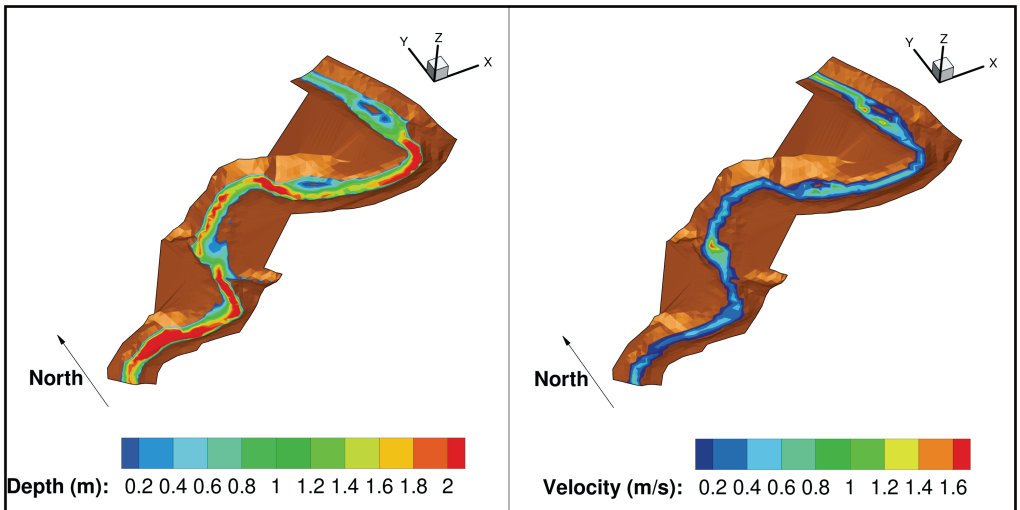

(a)

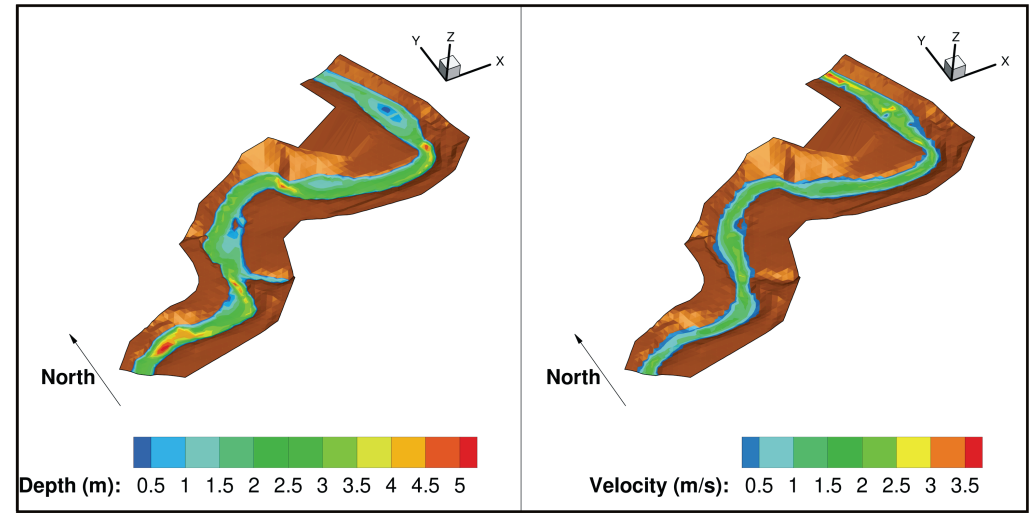

(b)

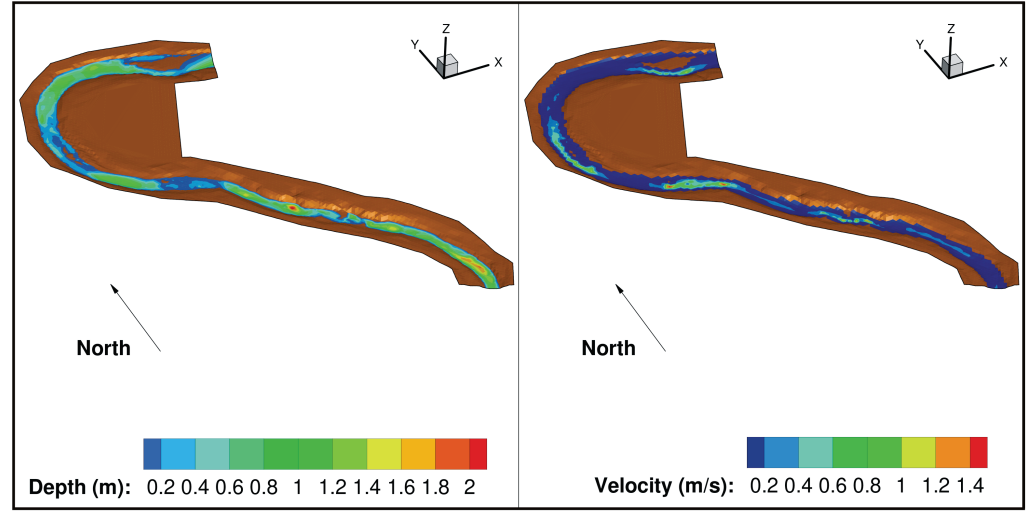

(c)

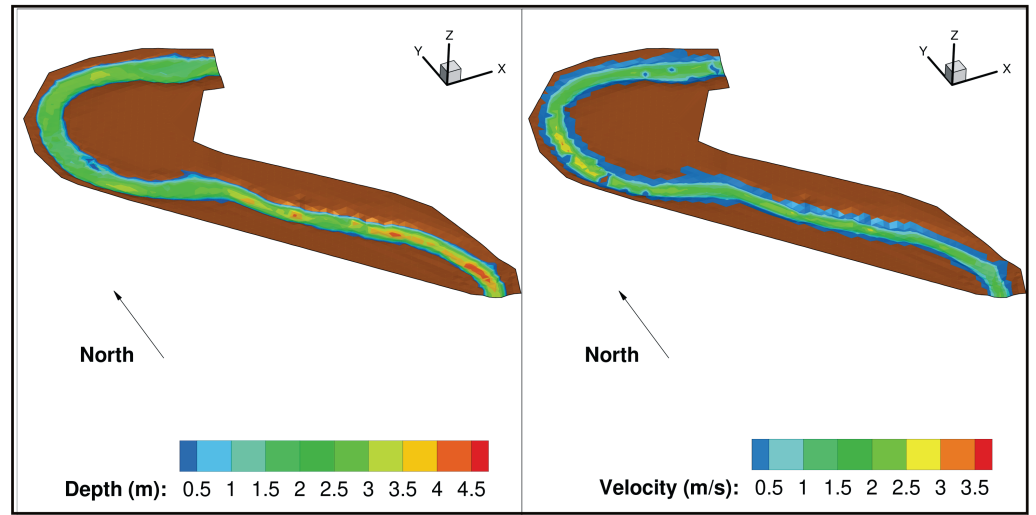

(d)

Fig. 5. Hydrodynamic (depth and water velocity) for the Velhas reach in the dry (a) and rainy (b) scenario; and for the Curimataí reach in the dry (c) the rainy (d) scenario. The reach length is $1 \mathrm{~km}$. 


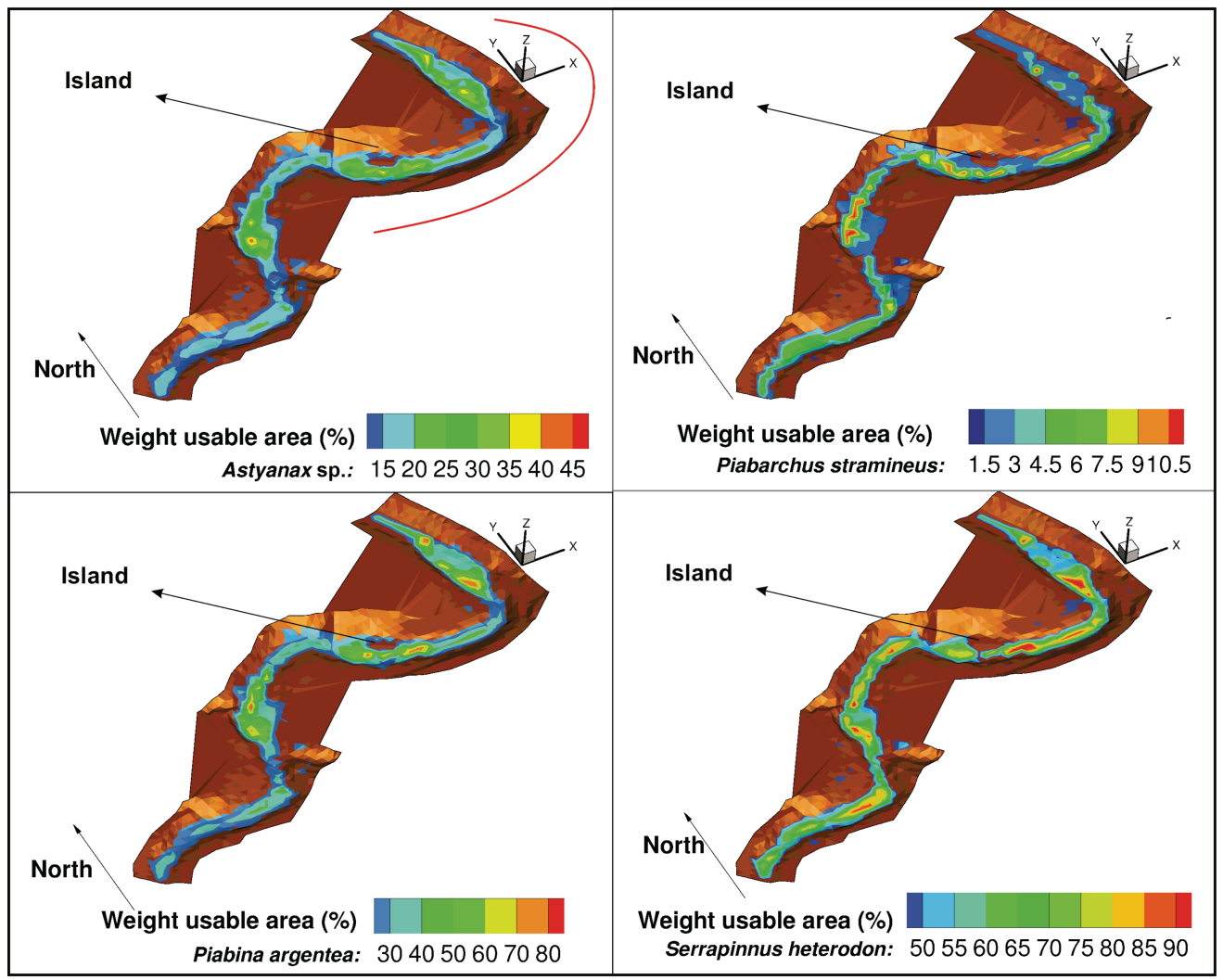

(a)

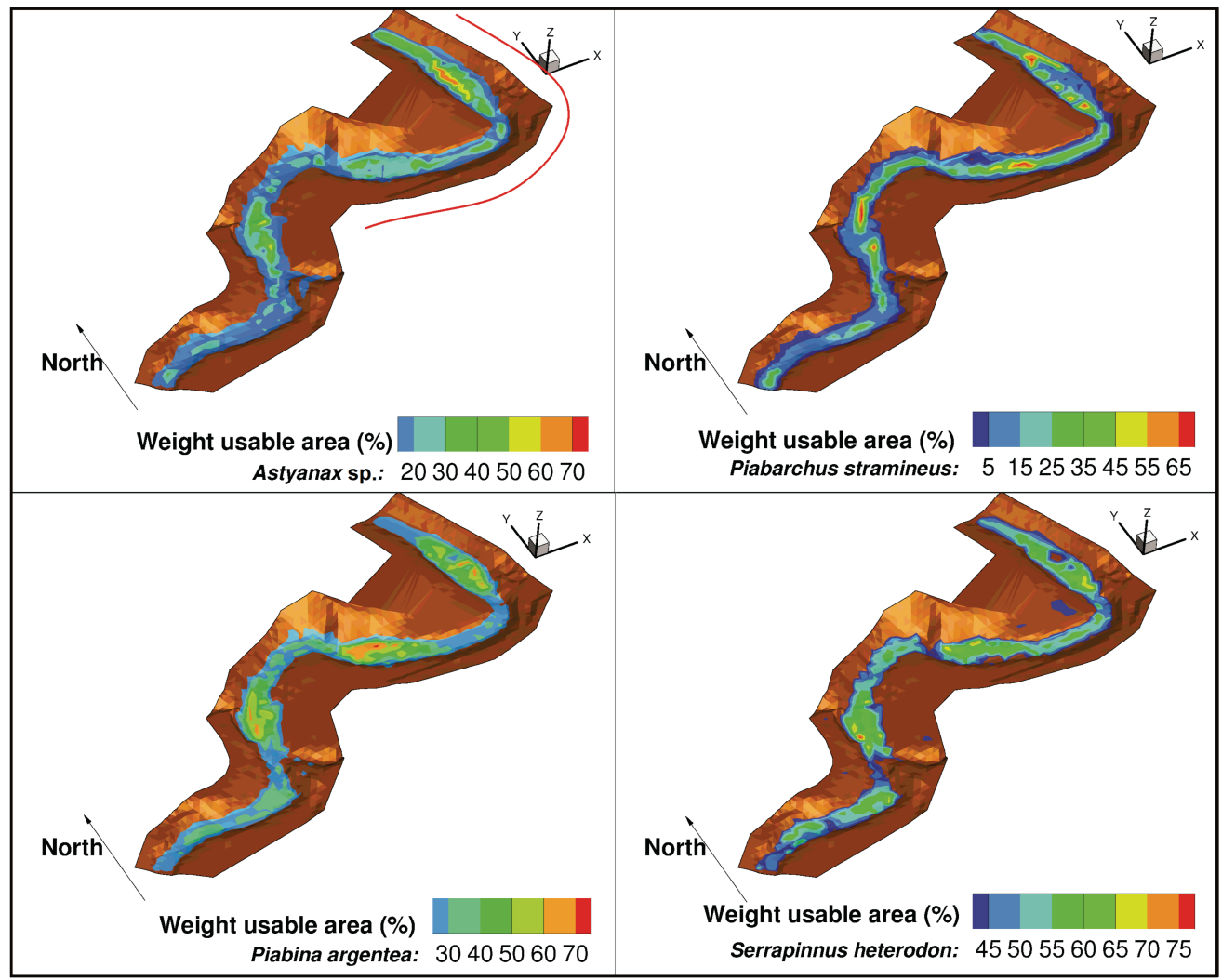

(b)

Fig. 6. Weight usable area (WUA) in percentage for four species at the Velhas reach in the dry scenario (a) and in the rainy scenario (b). Highest WUA is indicated in red and lowest WUA is indicated in dark blue. The reach length is $1 \mathrm{~km}$. The red line indicated the area along the reach where the habitat use was observed. 


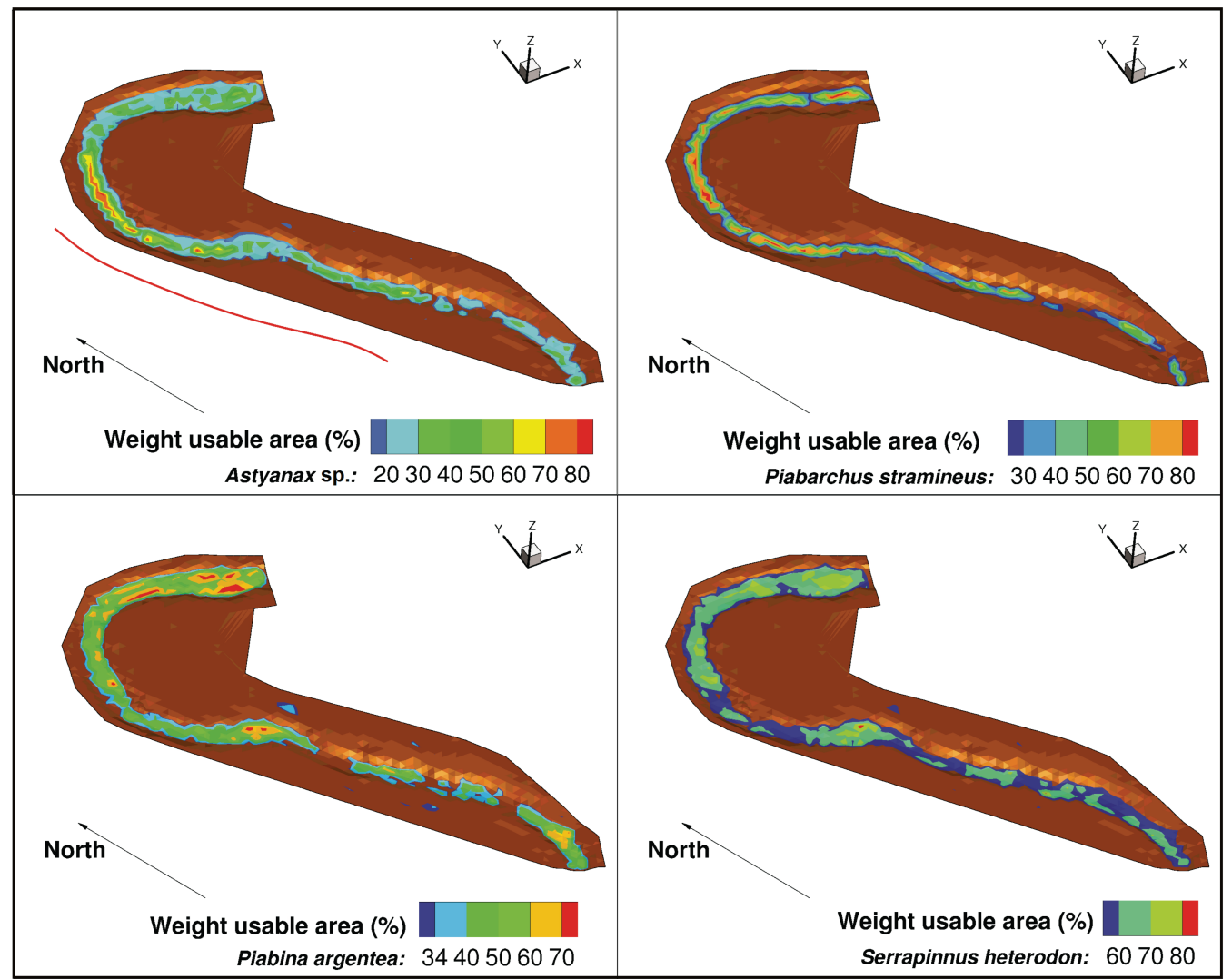

(a)

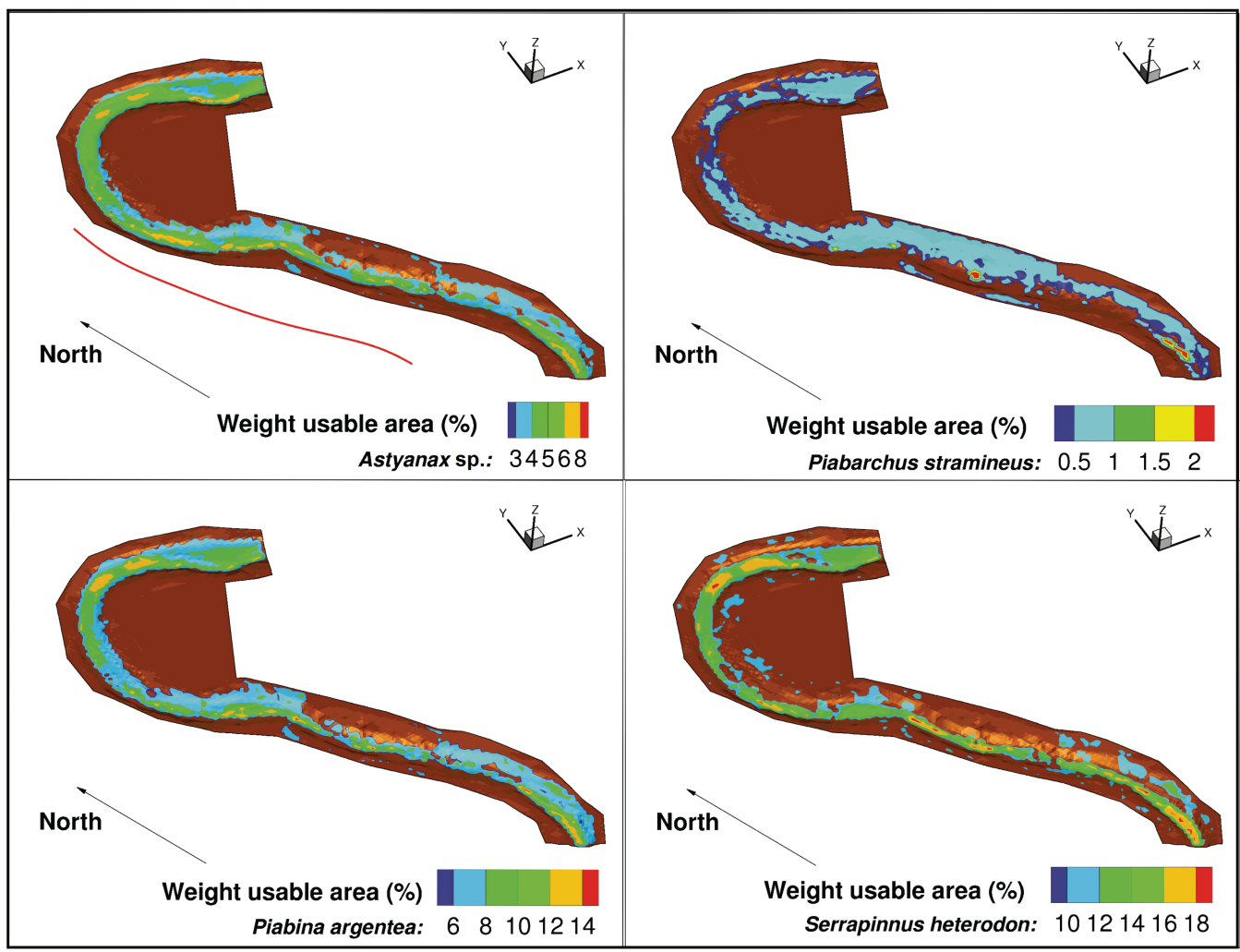

(b)

Fig. 7. Weight usable area (WUA) in percentage for four species at the Curimataí reach in the dry scenario (a) and in the rainy scenario (b). Highest WUA is indicated in red and lowest WUA is indicated in dark blue. The reach length is $1 \mathrm{~km}$. The red line indicated the area along the reach where the habitat use was observed. 


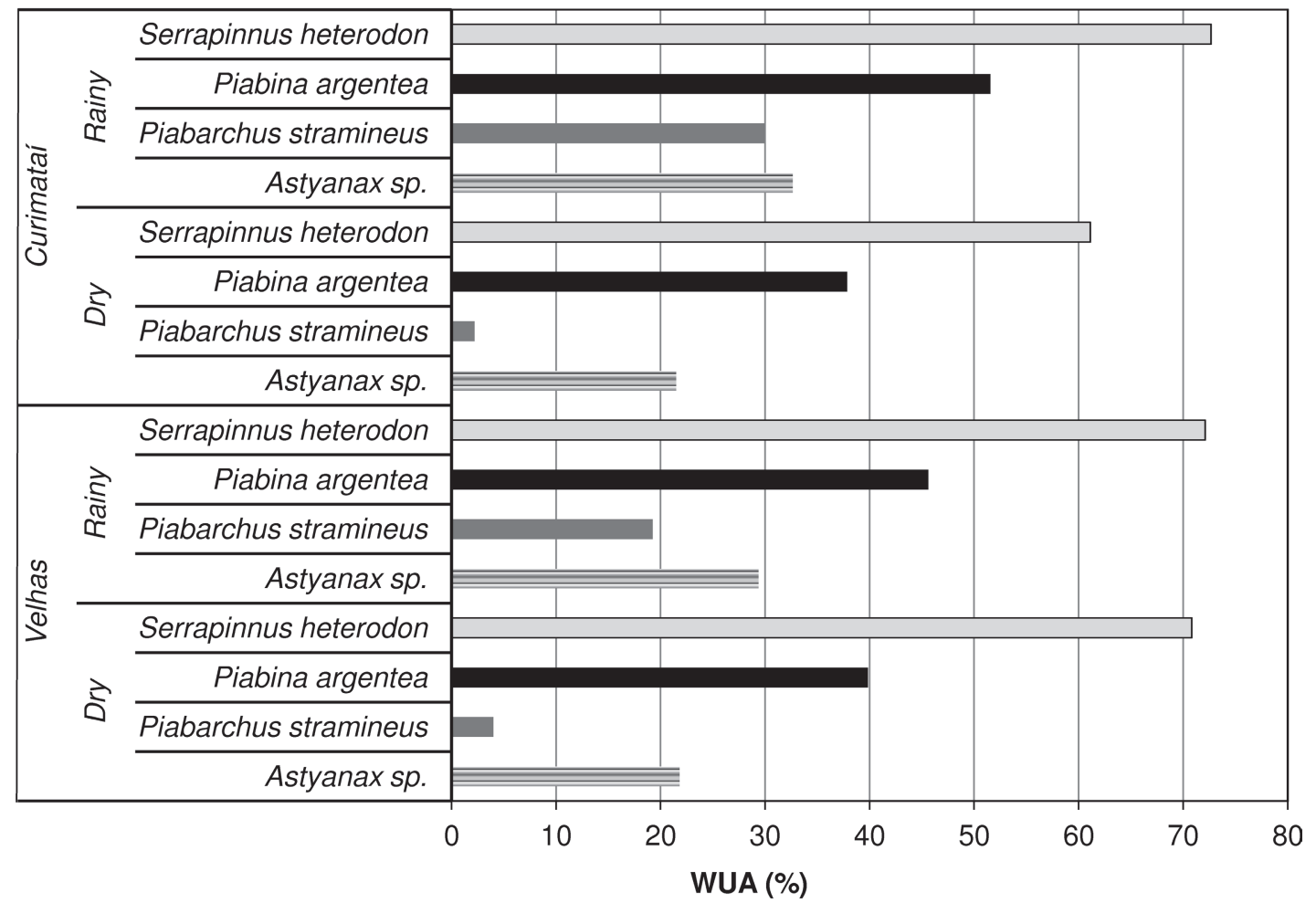

Fig. 8. Weight usable area in percentage of total area for four species in all scenarios and reaches. The reach length is $1 \mathrm{~km}$.

hand, in the dry scenario, the Velhas reach showed a higher WUA than that of the Curimataí. Therefore, the same hydrological flow percentiles may produce different habitat proportions in different rivers. This result indicates that hydrological methods, which provide flow percentiles, are inconsistent when compared to habitat availability scenarios.

Reaches with hydrological similarity might provide different amount of habitat for species because habitat availability is also a function of the riverbed. One of criticisms of the hydrological methods for environmental flow is that it does not consider local fish demands and the dynamic and variable nature of the hydrological regime (King et al., 2000) or the structural differences of the riverbed.

The PHABSIM indicated more habitat for three species at the Velhas reach than that of the Curimataí reach in the dry scenario. Those areas might be disconnected by areas of high velocity, which brings consequences to the effectiveness of the presence of physical habitats because the fish might be not able to access the habitat (by water velocity barrier). For species such as $P$. stramineus, a water velocity barrier might be created, for example, when the flow velocity is approximately $0.73 \mathrm{~m} / \mathrm{s}$ for specimens that have just reached sexual maturity (Castro et al., 2010). Therefore, the simple WUA analysis, proposed as the main result of PHABSIM, is weak in detecting the connectivity of these habitats. On the other hand, hydrological alterations, such as discharge reduction, might lead to habitat disconnection, and isolation has long been described as an important driver of stream fish population dynamics (Lonzarich et al., 1998).
Although the Velhas reach in the dry scenario had a higher habitat quantity for all species, three of them (Astyanax sp., $P$. stramineus and $S$. heterodon) were more abundant in the Curimataí reach. The hydrodynamic analyses showed that the water velocities and maximum depths for both scenarios (rainy and dry season) were higher at the Velhas reach than those at the Curimataí reach. This result might be an indication of the lack of stabilization of sediment transport in both the river bank and the bed of the Velhas reach.

In this study, the only species whose abundance followed the WUA index was $P$. argentea: 273 and 100 individuals were sampled in Velhas and Curimataí reaches, respectively. Leal et al. (2013) reported the plasticity of $P$. argentea, which uses different microhabitats in different river reaches in the Velhas River basin. In previous studies, $P$. argentea preferred areas deeper than $0.51 \mathrm{~m}$ and lower velocities (between 0 and $0.2 \mathrm{~m} / \mathrm{s}$ ) (Teresa, Casatti, 2013). Although we found similar results for depth preferences, $P$. argentea used more areas with velocities higher than $1 \mathrm{~m} / \mathrm{s}$. This result may indicate a fish adjusting to the presence of those habitats, as was reported in Leal et al. (2013).

The lack of providing levels of uncertainties associated with habitat suitability criteria (HSC) curves is the other criticism of the PHABSIM method (Ayllón et al., 2012). In this study, the adjustment of fish density for the four species using the generalized additive model showed different standards when they were compared to suitability curves, and they can help further studies of habitat projection for this species. Recently, new methods for transforming the traditional HSC curves using the generalized additive model 
(GAM) have been developed to add levels of uncertainties to fish occurrence by environmental variables (Shearer et al., 2015; Lin et al., 2015).

The GAMs allow the identification of spurious predictions in the affected regions of the habitat gradient by confidence intervals and enable correction by changing the effective degrees of freedom for the relevant smoothing function (Shearer et al., 2015). However, according Lin et al. (2015), different species distribution models, which are used to obtain HSC curves, will produce different means and standard deviations of the WUA values, which means that, in practice, decision-makers should be aware of the differences among projections caused by the model choice.

There is some uncertainty regarding the acceptable limits for the channel hydraulics. Predicted and measured depths and velocities at the Velhas and the Curimataí sites differed, on average, by $13 \%$. However, Bovee (1996) mentioned that the PHABSIM predicted depths and velocities are acceptable if they differ by approximately 10\%; Gallagher (1999) found differences of approximately $18 \%$ between the predicted and measured values. In this study, the difference was due to the position of the flowmeter and depth sounder, which depends on hand support to maintain stability against the water flow. These differences could also have been due to incomplete characterization of the spatial domain by the finite element mesh.

The general pattern of the Velhas and Curimataí reaches was the habitat increase (WUA) by the flow increase. The pattern makes sense for the habitat generalist species $(P$. argentea and $S$. heterodon), where increased flow means increased flood area and increased habitat, or it could be favored by higher velocities and/or deeper depths (Astyanax sp. and $P$. stramineus).

The Velhas and Curimataí rivers are non-regulated watercourses, which means that there is no significant dam in their way. However, the multiple water uses by industry plants, irrigation and human supply promote alterations in the flood peaks (Santos et al., 2012). In addition to those aspects, the minimum flow established by the Brazilian laws is only related to the hydrological aspect of rivers and depends on the state regulation information on what percentage of this reference discharge should be maintained on the river (CONAMA, 2005; Minas Gerais, 2012; Rio de Janeiro, 2007). In the Minas Gerais state, the minimum flow was calculated by the hydrological methodology of $\mathrm{Q}_{7,10}$ (the minimum average 7-day (consecutive) flow that is expected to occur once every 10 years).

A global review of environmental flow methodologies revealed that hydrological methodologies are the largest group ( $30 \%$ of the global total), are applied in all world regions and are the main methods applied in Central and South America (Tharme, 2003). The second most widely applied worldwide group of methodologies is the instream flow incremental methodology (IFIM), or other similarly structured approaches, with an emphasis on complex, hydrodynamic habitat modeling. The use of IFIM is remarkable in North
America and in developed countries of the Northern Hemisphere (Tharme, 2003). Actions that might have changed this scenario have been done with the release of important marks such as the Water European Directive in 2000 (Hering et al., 2010) and the Brisbane Declaration (http://www.watercentre.org/news/declaration) in 2007 (Poff et al., 2010). However, the implementation of these actions takes time, and the scientific literature was not able to capture the alterations in the global quantification of environmental flow methodologies.

The biological limitations of PHABSIM cause it to be overlooked by many biologists (Acreman et al., 2008), yet it is a useful tool that should not be considered a panacea (Spence, Hickley, 2000). The PHABSIM is the major component of IFIM and allows stakeholders to negotiate acceptable flow levels with other instream and out-of-stream water users in a variety of possible scenarios, in the same way that the other users had been doing for years (Waddle, 2012).

The selection of an appropriate environmental flow methodology for application in any country is likely to be context-specific and primarily constrained by the availability of appropriate data on the river system of concern, as well as local limitations in terms of time, funding, expertise and logistical support (King et al., 1999). Although the limitations of PHABSIM, which could be higher in Neotropical countries due to issues of megadiversity, the lack of Neotropical fish information, rare species and growing impacts on the basins, the methodology might be a better solution than steady parameters supplied by hydrological methods would be.

\section{Acknowledgments}

The Editors are very grateful to Carlos Alves, Lurdemar Paiva, Fernanda Horta, Marcos Callisto, Clarissa Dantas, Juliana França, Nara Junqueira and Marcela Cunha for their assistance in the field. We also would like to thank Projeto Manuelzão and Nuvelhas for logistic support and CNPq for financial support by CT-Hidro (555698/2006-8). Individual funding included scholarships from CNPq (304002/2014-3) and FAPEMIG to PSP, Programa de Capacitação Institucional (MPEG/MCTIC, CNPq 300231/2016-4) to CGL.

\section{References}

Acreman M, Dunbar M, Hannaford J, Mountford O, Wood P, Holmes $\mathrm{N}$ et al. Developing environmental standards for abstractions from UK rivers to implement the EU Water Framework Directive. Hydrol Sci J. 2008; 53(6):1105-20. Available from: http://dx.doi.org/10.1623/hysj.53.6.1105

Alves CBM, Pompeu PS. A fauna de peixes da bacia do rio das Velhas no final do século XX. In: Alves CBM, Pompeu OS, organizers. Peixes do rio das Velhas: passado e presente. Belo Horizonte: Segrac; 2001. p.165-187.

Alves CBM, Pompeu PS. Historical changes in the Rio das Velhas fish fauna - Brazil In: Rinne JN, Hughes RM, Calamusso B. editors. Historical changes in large river fish assemblages of 
the Americas. Bethesda: American Fisheries Society; 2005. p.587-602. (vol 45).

Armstrong JD, Nislow KH. Modelling approaches for relating effects of change in river flow to populations of Atlantic salmon and brown trout. Fish Manag Ecol. 2012; 19(6):52736. Available from: http://dx.doi.org/10.1111/j.13652400.2011.00835.x

Ayllón D, Almodóvar A, Nicola GG, Elvira B. The influence of variable habitat suitability criteria on PHABSIM habitat index results. River Res Appl. 2012; 28(8):179-88. http://dx.doi. org/10.1002/rra.1496

Barquín J, Martínez-Capel F. Preface: Assessment of physical habitat characteristics in rivers, implications for river ecology and management. Limnetica. 2011; 30(2):159-68. Available from: http://repositorio.unican.es:8080/xmlui/bitstream/ handle/10902/4217/Preface $\% 20$ Assessment $\% 20$ of\%20 physical $\% 20$ habitat $\% 20$ characteristics $\% 20$ in $\% 20$ rivers. pdf? sequence $=1$

Bovee KD. Development and evaluation of habitat suitability criteria for use in the instream flow incremental methodology. Washington (D.C): U.S. Fish and Wildlife Service; 1986.

Bovee KD. A comprehensive overview of the instream flow incremental methodology. Fort Collins: National Biological Service; 1996.

Bovee KD, Lamb BL, Bartholow J, Stalnaker CB, Taylor J, Henriksen J. Stream habitat analysis using the instream flow incremental methodology. Fort Collins: U.S. Geological Survey; 1998. Available from: https://www.fort.usgs.gov/sites/ default/files/products/publications/3910/3910.pdf

Bowen $\mathrm{ZH}$, Bovee KD, Waddle TJ. Effects of flow regulation on shallow-water habitat dynamics and floodplain connectivity. Trans Am Fish Soc. 2003; 132(4):809-23. Available from: http://dx.doi.org/10.1577/T02-079

Castro MA, Santos HA, Sampaio FAC, Pompeu PS. Swimming performance of the small characin Bryconamericus stramineus (Characiformes: Characidae). Zoologia 2010; 27(6):93944. Available from: http://dx.doi.org/10.1590/S198446702010000600015

Conselho Nacional de Meio Ambiente (CONAMA). Resolução CONAMA n ${ }^{\circ} 357$, de 17 de março de 2005 - Dispõe sobre a classificação dos corpos de água e diretrizes ambientais para o seu enquadramento, bem como estabelece as condições e padrões de lançamento de efluentes, e dá outras providências. Diário Oficial da União, Brasília; 2005.

Costa MR, Mattos TM, Borges JL, Araújo FG. Habitat preferences of common native fishes in a tropical river in Southeastern Brazil. Neotrop Ichthyol. 2013; 11(4):871-80. Available from: http://dx.doi.org/10.1590/S1679-62252013000400015

Freeman MC, Bowen ZH, Crance JH. Transferability of habitat suitability criteria for fishes in warmwater streams. N Am J Fish Manag. 1997; 17(1):20-31. Available from: http://dx.doi. org/10.1577/1548-8675(1997)017<0020:TOHSCF $>2.3 . C O ; 2$

Gallagher SP. Use of two-dimensional hydrodynamic modeling to evaluate channel rehabilitation in the Trinity River. Arcata: USAUS Fish and Wildlife Service; 1999.

Gomiero LM, Braga FMS. Reproduction of a fish assemblage in the state of São Paulo, southeastern Brazil. Braz J Biol. 2007; 67(2):283-92. Available from: http://dx.doi.org/10.1590/ S1519-69842007000200013

Gonçalves CS, Souza UP, Braga FMS. Population structure, feeding and reproductive aspects of Serrapinnus heterodon (Characidae, Cheirodontinae) in a Mogi Guaçu reservoir (SP), upper Paraná River basin. Acta Limnol Bras. 2011; 23(1):1322. Available from: http://dx.doi.org/10.4322/actalb.2011.014

Gore JA, Nestler JM. Instream flow studies in perspective. Regul River. 1988; 2(2):93-101. Available from: http://dx.doi. org/10.1002/rrr.3450020204

Hering D, Borja A, Carstensen J, Carvalho L, Elliott M, Feld CK, Heiskanen AS, Johnson RK, Moe J, Pont D, Solheim AL. The European water framework directive at the age of 10: a critical review of the achievements with recommendations for the future. SciTotal Environ. 2010; 408(19):4007-19. Available from: https://doi.org/10.1016/j.scitotenv.2010.05.031

Jowett I. Habitat Selection, version 1.0; 2011. Available from: http://www.jowettconsulting.co.nz/home/habprf

Katopodis C. Case studies of instream flow modelling for fish habitat in Canadian Prairie Rivers. Can Water Resour J. 2003; 28(2):199-216. Available from: http://dx.doi.org/10.4296/ cwrj2802199

King JM, Tharme RE, Brown CA. Definition and implementation of instream flows. Thematic report for the World Commission on Dams. Cape Town: Southern Waters Ecological Research and Consulting; 1999.

King JM, Tharme RE, De Villiers MS. Environmental flow assessments for rivers: manual for the Building Block Methodology. Pretoria: Water Research Commission; 2000.

Leal CG, Junqueira NT, Alves CBM, Pompeu PS. Morphological space stability in rivers under different disturbance regimes. Copeia. 2014; 2014(1):149-59. Available from: https://doi. org/10.1643/CE-12-096

Leal CG, Junqueira NT, Pompeu PS. Morphology and habitat use by fishes of the rio das Velhas basin in southeastern Brazil. Environ Biol Fishes. 2011; 90(2):143-57.

Leal CG, Junqueira NT, Santos HA, Pompeu PS. Variações ecomorfológicas e de uso de habitat em Piabina argentea (Characiformes, Characidae) da bacia do rio das Velhas, Minas Gerais, Brasil. Iheringia Ser Zool. 2013; 103(3):222-31. Available from: http://dx.doi.org/10.1590/S0073-47212013000300003

Lin YP, Lin WC, Wu WY. Uncertainty in various habitat suitability models and its impact on habitat suitability estimates for fish. Water. 2015; 7(8):4088-107. Available from: http://dx.doi. org/10.3390/w7084088

Lonzarich DG, Warren ML Jr., Lonzarich MR. Effects of habitat isolation on the recovery of fish assemblages in experimentally defaunated stream pools in Arkansas. Can J Fish Aquat Sci. 1998; 55(9):2141-49. Available from: https://doi.org/10.1139/ f98-113

Lourenço LS, Souza UP, Fernandes IM, Petrere M Jr. Spatiotemporal variation in life history traits of three small fishes in streams of south-eastern Brazil. Fish Manag Ecol. 2015; 22(2):143-51. Available from: https://doi.org/10.1111/fme.12114

Mazzoni R, Novaes VC, Iglesias-Rios R. Microhabitat use by Phalloceros harpagos Lucinda (Cyprinodontiformes: Poeciliidae) from a coastal stream from Southeast Brazil. Neotrop Ichthyol. 2011; 9(3):665-72. http://dx.doi.org/10.1590/ S1679-62252011005000027

Milhous RT, Bartholow JM, Updike MA, Moos AR. Reference manual for generation and analysis of habitat time series -Version 2 (No. FWS-90 (16)). Fort Collins: Fish and Wildlife Service; 1990.

MINAS GERAIS. Resolução Conjunta SEMAD-IGAM no. 1548, de 29 de março 2012. Dispõe sobre a vazão de referência para cálculo da disponibilidade hídrica superficial nas bacias hidrográficas do Estado. Diário do Executivo Minas Gerais, Belo Horizonte; 2012. 
Naiman RJ, Bunn SE, Nilsson C, Petts GE, Pinay G, Thompson LC. Legitimizing fluvial ecosystems as users of water: an overview. Environ Manage. 2002; 30(4):455-67. Available from: https:// doi.org/10.1007/s00267-002-2734-3

O'Keeffe J, Hughes D, Tharme R. Linking ecological responses to altered flows for use in environmental flow assessments: The flow Stressor-Response method. Verh Internat Verein Limnol., 2002; 28(1):84-92.

Poff NL, Richter BD, Arthington AH, Bunn SE, Naiman RJ, Kendy E, Acreman M, Apse C, Bledsoe BP, Freeman MC, Henriksen J et al. The ecological limits of hydrologic alteration (ELOHA): a new framework for developing regional environmental flow standards. Freshwater Biol. 2010; 55(1):147-70. Available from: http://dx.doi.org/10.1111/j.1365-2427.2009.02204.x

Reiser DW, Wesche TA, Estes C. Status of instream flow legislation and practices in North America. Fisheries. 1989; 14(2):22-9.

RIO DE JANEIRO. Portaria $\mathrm{n}^{\circ}$ 567, de 07 de maio de 2007. Estabelece critérios gerais e procedimentos técnicos e administrativos para cadastro, requerimento e emissão de Outorga de Direito de Uso de recursos hídricos de domínio do Estado do Rio de Janeiro, e dá outras providências. Rio de Janeiro. 2007.

Santos HA, Pompeu POS, Kenji DOL. Changes in the flood regime of São Francisco River (Brazil) from 1940 to 2006. Reg Environ Change. 2012; 12(1):123-32. Available from: https:// doi.org/10.1007/s10113-011-0240-y

Shearer KA, Hayes JW, Jowett IG, Olsen DA. Habitat suitability curves for benthic macroinvertebrates from a small New Zealand river. N Z J Mar Freshw. 2015; 49(2):178-91. Available from: https://doi.org/10.1080/00288330.2014.988632
Spence R, Hickley P. The use of PHABSIM in the management of water resources and fisheries in England and Wales. Ecol Eng. 2000; 16(1):153-8. Available from: https://doi.org/10.1016/ S0925-8574(00)00099-9

Steffler P, Blackburn J. Two-dimensional depth averaged model of river hydrodynamics and fish habitat. River2D user's manual, Edmonton: University of Alberta; 2002.

Teresa FB, Casatti L. Development of habitat suitability criteria for Neotropical stream fishes and an assessment of their transferability to streams with different conservation status. Neotrop Ichthyol. 2013; 11(2):395-402. Available from: http:// dx.doi.org/10.1590/S1679-62252013005000009

Tharme RE. A global perspective on environmental flow assessment: emerging trends in the development and application of environmental flow methodologies for rivers. River Res Appl. 2003; 19:397-441. Available from: http:// dx.doi.org/10.1002/rra.736

University of Alberta (UA), River 2D, version 0.95; 2002. Available from: http://www.river2d.ualberta.ca/download.htm

Waddle TJ. PHABSIM for Windows user's manual and exercises. Fort Collins: U.S. Geological Survey; 2012.

World Commission on Dams (WCD). Dams and development. a new framework for decision-making. The report of the World Commission on Dams. London: Earthscan Publications; 2000.

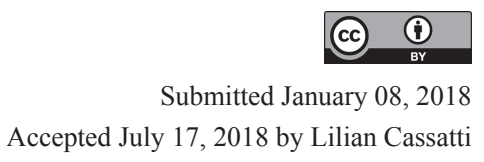

